\title{
Resistenza larga o resistenza stretta?
}

Roberto Chiarini

Storicamente, 2 (2006).

ISSN: 1825-411X. Art. no. 63. DOI: 10.12977/stor535

30 marzo 2006

Prof. Roberto Chiarini

(Università degli Studi di Milano)

Resistenza larga o resistenza stretta? 